\title{
Assessment of Drinking and Irrigation Groundwater Quality in Bundung-West Coast, Gambia
}

\author{
${ }^{* 1}$ TALHA, IZ; ${ }^{1}$ DARBOE, S; ${ }^{2}$ SHARU, MB \\ ${ }^{1}$ School of Agriculture and Environmental Sciences, University of the Gambia PMB 144 West Coast Region, Faraba - The Gambia \\ ${ }^{2}$ Department of Agricultural Science, Shehu Shagari College of Education, Sokoto, Nigeria \\ *Corresponding Author Email: zannahtalha@gmail.com; Tel: +2203145454, +2348032455460
}

\begin{abstract}
Laboratory investigation performed to examine the suitability of groundwater quality from an open well, cover well and tap water for drinking and irrigation purposes around Bundung West Coast of the Gambia. The overall mean values obtained are; $\mathrm{pH}(7.89)$, Temperature $\left(26.5^{\circ} \mathrm{C}\right)$, Electrical Conductivity $(1070.8 \mathrm{mS} / \mathrm{cm})$, Total Dissolved Solids $(696.00 \mathrm{mg} / \mathrm{l})$, Salinity $(0.44 \%)$ and Faecal Coliforms $(55.2 / 100 \mathrm{ml})$. The Coefficient of Variability $(\mathrm{CV})$ among samples for each analytical parameter was $>1$, reflecting inconsistency among analysed samples. Nitrate $(9.2 \mathrm{mg} / \mathrm{l})$, Phosphate $(0.81 \mathrm{mg} / \mathrm{l})$, Sulphate $(6.2 \mathrm{mg} / \mathrm{l})$, Ammonia $(1.61 \mathrm{mg} / \mathrm{l})$, Nitrite $(0.010 \mathrm{mg} / \mathrm{l})$, Total Hardness $(273.9 \mathrm{mg} / \mathrm{l})$ and Alkalinity $113.5 \mathrm{mg} / \mathrm{l})$ had shown high variance among samples in the site $(\mathrm{CV}>1)$. Results of Total Hardness (273.9), is indicative of contaminated groundwater. The microbiological properties exposed colonies of microorganisms (coliforms) resulting from contamination by faecal matter or seeping of sewage effluent into the groundwater and hence unfit for consumption. The groundwater samples in the study site were under high salinity class $(>2250 \mu \mathrm{S} / \mathrm{cm})$, unsuitable for irrigation agriculture. The coefficient of variability is $>1$, high variance among samples in the entire site. Total Dissolved Solids $(\mathrm{CV}>1)$ contents of the groundwater can be fit only for tolerant crops. The findings suggest that groundwater is unsafe for drinking purposes without decontamination, and measures should be in place for quality water for irrigation agriculture.
\end{abstract}

\section{DOI: $\underline{\text { https://dx.doi.org/10.4314/jasem.v23i11.4 }}$}

Copyright: Copyright $($ C) 2019 Talha et al. This is an open access article distributed under the Creative Commons Attribution License (CCL), which permits unrestricted use, distribution, and reproduction in any medium, provided the original work is properly cited.

Dates: Received: 07 October 2019; Revised: 11 November 2019; 24 November 2019

Keywords: Groundwater, quality indicators, domestic use, Irrigation

Groundwater is an important resource for drinking and irrigation agriculture. Human activities including agriculture need ample quantities of quality water to meet up with the increasing demand for food by the ever-growing world population. The growing population of the Gambia intensifying agricultural and urban development has resulted in a high demand for groundwater resources driving these resources at greater risk to contamination. The scope of intervention in terms of both water quality and quantity is currently below what is required to maximize production. All water contains natural contaminant, particularly inorganic contaminant that arises from the geological strata through which the water flows and to varying extent, anthropogenic pollution by both microorganisms and chemicals (Hayzoun et al., 2014). Their suitability for domestic use is directly related to different physical and chemical parameters and their concentrations (Chaudhary and Satheeshkumar, 2018). Water, sanitation and hygiene factors accounted for 13.5 percent of all deaths in the Gambia (World Health Organization, 2016). The impact on child mortality rates is devastating due to unsafe drinking water, poor sanitation and hygiene (Boisson et al., 2016). Contaminated water is a core issue on climate regulation and natural ecosystems affecting not only human health but also water quality for irrigation, economic development, and social prosperity in the Gambia. The quality of groundwater is equally important to its quantity owing to the suitability of water for various drives (Prasanth $e t$ al., 2012). Globally, irrigation is the highest consumptive use of freshwater (Gerten et al., 2013). The relative consumptive use of freshwater in the Gambia accounted for $67 \%$ (Frenken, 2005). The existing advancing degrees of irrigation demands on the world's freshwater resources are unsustainable (Connor, 2015). The suitability of groundwater for domestic use and irrigation purpose is determined by its geochemistry (Ramachandran et al., 2012). It is also influenced by the geochemical reactions in the aquifers and soils when supplied via inappropriate channels for irrigation (Li et al., 2013). The groundwater chemistry and its diversity are a subject of the over-all geology, varying degrees of chemical weathering of the individual rocks, quality of recharge water and inputs from sources other than water interaction. These factors and their interactions end in a complex groundwater quality (Aghazadeh and Mogaddam, 2010). The undesirable change on the quality of water 
in some parts of the Gambia might be due to changes in natural or physical, chemical, biological characteristics of water, convoyed with some social problems such as unplanned urbanization, improper management of waste, use of chemicals and other related hazardous substances. In spite of the efforts from the Gambia authorities by chlorinating and aerating the water coming from boreholes for community use, yet there are several contaminations either at point source or after treatment along the pipes or at the point of collection.

Some households are still using well water for cooking and other domestic use, which are not treated by any means. This might have several detrimental effects on the populace. In recent time the well waters in Bundung Bohole in the Gambia are found to be unpalatable, and cannot easily foam with soap, that lead to the closure of the source by the Gambian authorities. The Bundung water sources situated at the West Coast of the Gambia has been selected for the study, to address such fundamental issues relating to poor water quality for drinking and irrigated agriculture, there must be sound planning to ensure frequent or intermittent water quality assessment for use.

This supports further in creating awareness as some of the environmental pollutions are manmade, getting their way into the water body through erosion, percolation or seeping wastewater or chemicals into the groundwater. Therefore, the objective was to examine the physical, chemical, and biological properties of the groundwater to assess its suitability for drinking and irrigation purposes.

\section{MATERIALS AND METHODS}

Study Site and Hydrogeological Backgrounds: The study area is located within the The Gambia State situated between the $13.4198^{\circ} \mathrm{N}$ and $16.6851^{\circ} \mathrm{W}$ in Bundung in the Western Coast Region. The climate is Sudan-Sahelian in nature as described by Lawson and Jaworski (2007), characterized by a unimodal rainfall pattern. Mean daily temperatures during the cropping season ranged between $23^{\circ} \mathrm{C}$ and $33^{\circ} \mathrm{C}$ (Camara, 2012). Due to the extensive surface water, at the mouth of the river, high salinity is a problem in surface water supplies, resulting in rare or no consumption as drinking water. The shallow sand aquifer covers nearly the whole country, made up of Holocene sediments and an underlying, partially confined Pliocene aquifer. The sand aquifer ranges between 5 and 25 meters thick. The country also has a deep sandstone aquifer, with fossil water as much as 40,000 years confined at depths of 250 to 450 meters. Out of the total storage of 650,000 cubic meters, only 80,000 cubic meters are believed to be potable (Dochartaigh and Brighid, 2019). The Gambia is underlain almost entirely by recent geologic Cenozoic sedimentary rocks. Much deeper basement rocks are likely existing. The geology of Gambia is defined by thick and relatively recent sequences of sediments deposited 66 million years ago (Schlüter, 2008).

Sample Collection and Analysis: A total of 15 groundwater samples were collected from were collected using standard sampling procedures in April 2019 from three (3) regions namely; Bundung region, Serrekunda central and Kanifing municipal council. The categorization was based on different water sources used in the localities. Detail description of collected samples are shown below (Table 1).

Table 1 Description of collected samples

\begin{tabular}{lll}
\hline Sample & Description / Sample type & Location \\
\hline 1 & Open well in the women garden & In a women garden \\
2 & Open well for domestic use in a home & Njie kunda \\
3 & Open well very close to septic tank for domestic use & Gaye kunda \\
4 & Tap water from National water and electricity company & Darboe kunda \\
5 & Cover well very close to septic tank for domestic use & Jallow kunda \\
\hline
\end{tabular}

The site has a sloppy topography, an elevated area. It has sparse vegetation due to the presence of young soils. The deposition of sand is ongoing due to runoff. Detail sampling sites are shown (Figure 1). Collected samples were immediately measured for electrical conductivity (EC), $\mathrm{pH}$, temperature, turbidity, salinity and total dissolved solids (TDS) by digital meters in situ. The collected samples were stored in iceboxes after filtration and brought for further chemical analysis. The water samples were analysed for various chemical constituents (nitrate, phosphate, sulphate, ammonia, and nitrite) using Spectrophotometer using the standard photometric technique. The samples collected for the experiment were also assessed for total and faecal coliform as described by (Rice et al., 2012). The quality of water and its contamination rate are evaluated based on WHO/USDA guidelines and validated standards.

\section{RESULTS AND DISCUSSION}

The physical, chemical and microbiological parameters are key factors used in examining water quality suitability for consumption and irrigation. Analytical parameters from varying properties are in 
Tables 2, 3, and 7. Discussion on the suitability of the collected groundwater samples for drinking and irrigation purposes was done independently with the recommended standard as guidelines from WHO and FAO/USDA. Suitability of the groundwater for drinking: The suitability of groundwater for drinking is directly linked to different physical and chemical individual parameters and their concentrations. The $\mathrm{pH}$ of groundwater of all samples ranged from 7.56 to 8.14 , which are within the permissible limits described by WHO chronicle (6.5-8.5) (Edition, 2011). The maximum $\mathrm{pH}$ value (8.14) was observed in the open well in the women garden in Bundung West Coast region of The Gambia. All the water samples were designated to be neutral to alkaline in nature. The electrical conductivity (EC) of the groundwater was in the range of $642.00-2120.00 \mathrm{mS} / \mathrm{cm}$. Sample $3(2120$ $\mathrm{mS} / \mathrm{cm}$ ) shown in (Table 2) is above the permissible limit.

\begin{tabular}{|c|c|c|c|c|c|c|c|c|c|c|}
\hline Sample no. & $\mathrm{pH}$ & $\begin{array}{l}\text { Temp. } \\
\left({ }^{\circ} \mathrm{C}\right)\end{array}$ & $\begin{array}{l}\mathrm{EC} \\
\mathrm{mS} / \mathrm{cm}\end{array}$ & $\begin{array}{l}\text { TDS } \\
\mathrm{mg} / 1\end{array}$ & $\begin{array}{l}\text { Salinity } \\
(\%)\end{array}$ & $\begin{array}{l}\mathrm{TC} / 100 \mathrm{ml} \\
\mathrm{no} / 100 \mathrm{ml}\end{array}$ & $\begin{array}{l}\mathrm{FC} / 100 \mathrm{ml} \\
\mathrm{no} / 100 \mathrm{ml}\end{array}$ & $\begin{array}{l}\mathrm{R} . \mathrm{Cl} 2 \\
\mathrm{mg} / \mathrm{l}\end{array}$ & Turb. & Odor \\
\hline 1 & 8.14 & 26.6 & 642.00 & 417.00 & 0.31 & $>100$ & 48 & 0 & $<5$ & Normal \\
\hline 2 & 7.90 & 25.6 & 1153.00 & 750.00 & 0.57 & $>100$ & 68 & 0 & $<5$ & Normal \\
\hline 3 & 7.56 & 26.5 & 2120.00 & 1378.00 & 1.08 & $>100$ & 88 & 0 & $<5$ & Normal \\
\hline 4 & 7.78 & 27.2 & 200.00 & 130.00 & 0.09 & 0 & 0 & 0.26 & $<5$ & Normal \\
\hline 5 & 8.06 & 26.5 & 1239.00 & 805.00 & 0.16 & $>100$ & 72 & 0 & $<5$ & Normal \\
\hline Overall $\overline{\mathrm{x}}$ & 7.89 & 26.5 & 1070.8 & 696.00 & 0.44 & 0 & 55.2 & 0.052 & 0 & Normal \\
\hline SD & 0.21 & 0.51 & 644.68 & 419.075 & 0.36 & 0 & 30.4 & 0.104 & 0 & - \\
\hline $\mathrm{CV}$ & 2.61 & 1.93 & 60.21 & 60.21 & 81.21 & 0 & 55.07 & - & - & - \\
\hline WHO standard & $6.5-8.5$ & Acceptable & 1300 & 1000 & NS & 0 & 0 & 250 & $<5$ & Normal \\
\hline
\end{tabular}

EC - electrical conductivity, TDS - total dissolved solids, FC - Faecal coliform, R.Cl2 - Chlorine $\overline{\mathrm{x}}$ - Mean, SD-standard deviation CVcoefficient of variability

The electrical conductivity as a measure of water capacity to convey electric current, it signifies the amount of total dissolved salts, which indicates the presence of high amount of dissolved inorganic substances in ionized form. It directly shows the presence of higher levels of cations and anions. The conductivity increases as the concentration of TDS increases (Table 2). The TDS values ranged between 130.00 and $1378.00 \mathrm{mg} / \mathrm{l}$. Results of sample 3 collected from Open well in Gaye Kunda catchment showed higher values. The open well was found to be close to a septic tank. The higher values of TDS in this catchment are indicative of the presence of a significant amount of soluble salts concentrations, classified as unsafe for consumption (Edition, 2011 WHO). TDS is the total concentration of substances, including inorganic salts and organic matter that dissociates in a given volume of water. TDS and conductivity affect the water sample and the solubility of slightly soluble compounds and gases in water (Gray, 2017).

\begin{tabular}{|c|c|c|c|c|c|c|c|}
\hline Sample number & $\begin{array}{l}\text { Nitrate } \\
\mathrm{NO}_{3}^{-}-\mathrm{mg} / 1\end{array}$ & $\begin{array}{l}\text { Phosphate } \\
\mathrm{PO}_{4}^{-3} \mathrm{mg} / \mathrm{l}\end{array}$ & $\begin{array}{l}\text { Sulphate } \\
\mathrm{SO}_{4}^{-2} \mathrm{mg} / \mathrm{l}\end{array}$ & $\begin{array}{l}\text { Ammonia } \\
\mathrm{NH}^{+4} \mathrm{mg} / \mathrm{l}\end{array}$ & $\begin{array}{l}\text { Nitrite } \\
\mathrm{NO}_{2}^{-}-\mathrm{mg} / \mathrm{l}\end{array}$ & $\begin{array}{l}\text { Total } \\
\text { Hardness mg/l }\end{array}$ & $\begin{array}{l}\text { Alkalinity } \\
\mathrm{mg} / \mathrm{l}\end{array}$ \\
\hline 1 & 3.10 & 1.52 & 0 & 0.30 & 0.012 & 120.0 & 155.8 \\
\hline 2 & 6.30 & 0.91 & 4 & 2.00 & 0.017 & 273.3 & 90.2 \\
\hline 3 & 20.60 & 0.34 & 16 & 3.18 & 0.012 & 634.4 & 98.4 \\
\hline 4 & 3.60 & 0.76 & 0 & 0.30 & 0.002 & 48.8 & 26.2 \\
\hline 5 & 12.40 & 0.54 & 11 & 2.25 & 0.008 & 292.8 & 196.8 \\
\hline Overall $\overline{\mathrm{x}}$ & 9.2 & 0.81 & 6.2 & 1.61 & 0.010 & 273.9 & 113.5 \\
\hline SD & 6.591 & 0.4 & 6.3 & 1.14 & 0.005 & 202.3 & 58.5 \\
\hline $\mathrm{CV}$ & 71.64 & 49.5 & 102.2 & 70.77 & 48.98 & 73.88 & 51.56 \\
\hline WHO standard & 10 & 0.33 & 250 & 0.5 & 0.03 & 200 & 200 \\
\hline
\end{tabular}

Table 4 Classification of analysed samples for total hardness WHO chronicle (Edition, 2011) (n=3)

\begin{tabular}{lll}
\hline Samples & Total hardness $(\mathrm{mg} / \mathrm{l})$ & Nature of the water \\
\hline 1 & 120.0 & Moderate \\
2 & 273.3 & Very hard \\
3 & 634.4 & Very hard \\
4 & 48.8 & Soft \\
5 & 292.8 & Very hard \\
\hline
\end{tabular}

Total hardness $(\mathrm{TH})$ of groundwater from analysed samples (Table 4) was in the range of 48.8-634.4 mg/l.
The results confirmed that only sample 1and 4 are within the permissible limit for safe consumption 
(Edition, $2011 \mathrm{WHO}$ ). The groundwater analysis for total hardness (TH) except sample 1 and 4 shows that these samples fall under the very hard water category (Table 4). The hardness of water is due to the presence of alkaline earths such as calcium and magnesium, existing in bicarbonate forms. Calcium and magnesium are found in groundwater when the underground rock strata contain certain rock minerals such as limestone and gypsum that dissolved in the water (Ford and Williams, 2013). The calcium and magnesium bond with sulphates, chlorides, carbonates contribute to the hardness of water in wells. Quite several inquiries have established a link between health-related problems and the hardness of drinking water (Momeni et al., 2014). Alkalinity is a measure of the capacity of water to neutralize acids or hydrogen ion. Groundwater becomes alkaline when it contains carbonates from rock minerals that dissolved in water. Results show all analysed samples are within the permissible limit for safety $<200$. (Table 3). Groundwater is the major source of drinking or domestic supply in the Gambia, its contamination due to pathogens and dissolved salts and chemicals demands frequent monitoring for drinking water and other domestic use. After the microbiology test for both treated water (sample 4) and untreated well water (sample 1,2, 3 and 5), there were elevated concentration of microorganism that grow on pink filter path in a form of colonies that are too numerous to count except for sample 4 where there was no growth of microbes on the media due to treatment received before usage. Total Faecal Coliforms are naturally occurring bacteria found in living organisms. The presence of Faecal Coliforms indicates contamination by sewage waste. It is also indicative of the presence of disease-causing organisms in the water body (Pandey et al., 2014). The presence of coliforms also indicates contamination by faecal matter or seeping of sewage effluent into the groundwater. If the total and faecal coliform count exceeds zero that is the permissible limit for the WHO standard, it is not safe for consumption due to the risk of pathogenic diseases. Therefore, sample 4 is the only sample that meets the requirement.

The ammonia analytical result ranged from 0.30 to $3.18 \mathrm{mg} / 1$ (Table 3). Sample 1 and 4 are permissible for safe drinking as described by the WHO guidelines. The ammonia concentrations in samples 2,3 , and 5 are beyond the limit recommended for safe drinking. The contamination was a consequence of sewage wastes and other wastes rich in nitrates around interfering with the groundwater. Ammonia has positively charged ions, formed by the addition of hydrogen to ammonia. When water reacts with ammonium, it gives ammonia and hydroxide as a by-product. It can depend on $\mathrm{pH}$, temperature, and dissolved salts in water. It is being generated from sewage effluent (Eskicioglu et al., 2018). According to Rout (2011), Sulphur in groundwater is normally present in a form of sulphate. Sulphur may enter into groundwater through weathering of sulphide bearing deposit. The acceptable limit of sulphate is $250 \mathrm{mg} / \mathrm{l}$ as shown in (Table 3). Sulphate concentration in the analysed samples varied from 0 to $16 \mathrm{mg} / 1$ and all samples are within the permissible. Sulphate in groundwater mainly occurs due to sulphate mineral dissolution and sulphide mineral oxidation. Phosphate has been a constituent in agricultural fertilizers and organic waste. Sewage is essential for plant growth, but too much of it in water can affect water quality. The water samples analysed for the concentrations of phosphate ranged from 0.34 to $1.50 \mathrm{mg} / 1$, indicative of phosphate in the water. The permissible limit set by WHO is $0.33 \mathrm{mg} / \mathrm{l}$. Therefore, all the analysed samples values are beyond the recommended range for drinking and domestic usage. The nitrate concentrations in the analysed samples varied from 3.10 to $20.60 \mathrm{mg} / 1$. Samples 3 and 5 are beyond the permissible limit of WHO guidelines $(10 \mathrm{mg} / \mathrm{l})$. The contamination is due to the proximity of animals around rearing, causing surface pollution. Oxidation of ammonia form of nitrogen from animal and human wastes to form nitrite is a possible way of entry into the groundwater aquifer (Palamuleni and Akoth, 2015). The primary health hazard from drinking water with nitrate-nitrogen occurs when nitrate becomes nitrite in the digestive system. The nitrite oxidizes combined with iron in the hemoglobin of the red blood cells to form methemoglobin, which lacks the oxygen-carrying ability of hemoglobin to the individual body cells causing the veins and skin to appear blue, largely affecting bottle-fed children or babies (Seth et al., 2014). On the other hand, the least nitrite concentration was found in sample $4(0.002 \mathrm{mg} / \mathrm{l})$, while sample 2 had the highest value $(0.017 \mathrm{mg} / 1)$. The permissible limit recommended for safety is $0.03 \mathrm{mg} / \mathrm{l}$. Therefore, all the analysed samples are safe for use or drinking. Salinity is the percentage of salt in a sample. The concentration of the soluble salts analysed varied from $0.09 \%$ to $1.08 \%$. The water samples analysed are clear, meaning they are not turbid. The odours are normal.

Groundwater quality criteria for irrigation and suitability: Irrigated agriculture is dependent on the adequate water supply of usable quality (Chaudhary and Satheeshkumar, 2018). Soils in the Gambia are largely ferruginous and feralitic characterized by low Cation Exchange Capacity (CEC), low intrinsic fertility, strong consistencies, and poorly developed structures and medium to high base saturation (CSOCLASS, 2008). Most of the land surface is from 
sandstone laid down during the late Tertiary period. The deposit Continental Terminal is a highly weathered detrital sediment made up of clayey sandstone with intercalated discontinuous quartz gravel, sand and clay. (Schlüter, 2008). Soil degradations in the Gambia include; soil erosion, clearing by burning and limited use of organic fertilizers and salinization (Fatajo, 2010). The soils are generally well-drained to excessively drained and have low moisture retention capacity and high permeability. Thus, in such soil conditions, irrigation water quality staples for good and sustainable irrigation water supply. In assessing the salinity index, electrical conductivity is a useful and reliable tool for the measurement of water salinity or total dissolved solids in water. The most influential water quality index on crop productivity is the water salinity measured by electrical conductivity (EC) (Bauder et al., 2011). Electrical conductivity occurs from ionization of dissolved inorganic solids minerals, salts, metals, cations or anions that dissolved in water. It plays a vital role in the suitability of water for irrigation (Chaudhary and Satheeshkumar, 2018). The accumulation of soluble salts affects the growth of plants. It also affects soil structure, permeability, and aeration, affecting plant growth (Sudhakar and Narsimha, 2013). It is evident from Tables 5 and 6 that all of the groundwater in question were under high salinity class with exception to sample 4 permissible for use.

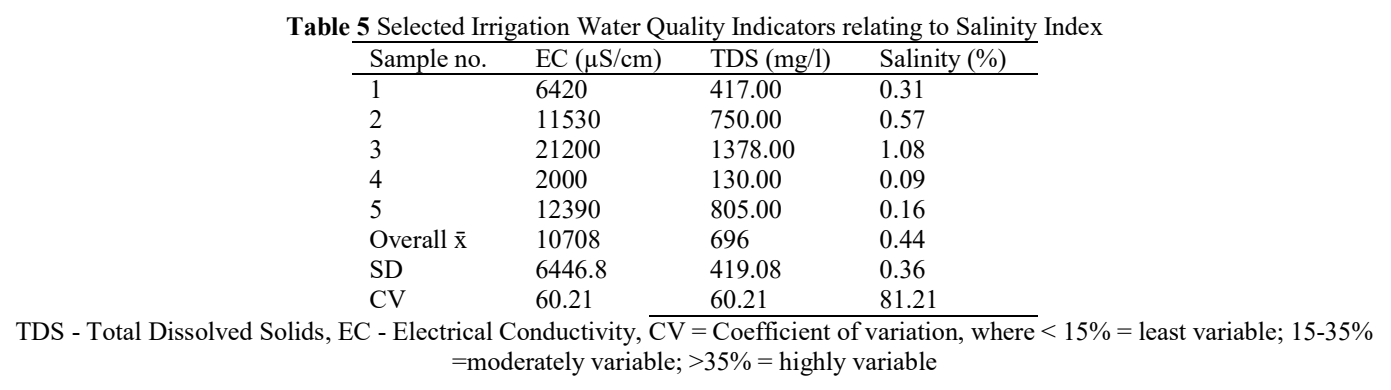

Table 6 Groundwater suitability for Irrigation according to the guideline established by USDA based on EC

\begin{tabular}{|c|c|c|c|}
\hline $\mathrm{EC}(\mu \mathrm{S} / \mathrm{cm})$ & Salinity class & Number of samples & Quality remark \\
\hline$<250$ & $\mathrm{C} 1$ & & Excellent \\
\hline $250-750$ & $\mathrm{C} 2$ & & Good \\
\hline $750-2250$ & $\mathrm{C} 3$ & 4 & Permissible \\
\hline$>2250$ & $\mathrm{C} 4$ & $1,2,3,5$ & Unsuitable \\
\hline
\end{tabular}

Other samples are suitable only for irrigating salttolerant crops. Salinity is a product of weathering of rocks and release of soluble salts in the groundwater, primarily chlorides of sodium, calcium, magnesium, sulphates, and carbonates to a reduced amount. The Gambia has a tropical climate with distinct dry and rainy seasons. Irrigation water salinity is expected to be high. The greater amount of dissolved soluble salts in irrigation water in the root zone of the plants reduces uptake of water due to a high concentration of soil solution for salt accumulated, destroying the plants' cells and hence affecting crop growth and yield (Rasool et al., 2013). The concentration of soluble salts is one of the conventional indicators for the suitability of water. Concentration of highly soluble salts in water increases the salinity of the soil, whereas the low-solubility salts precipitate and accumulate in the soil for successive (Murtaza, 2011). The mean salinity values of the studied samples varied from 0.91 to 1.08 in all the groundwater in that area. Several works had shown that chloride is not adsorbed by soils but it moves readily with the soil-water into the crop (Ogunfowokan et al. 2013; Murtadha et al. 2017). The mechanism involved is that it joins the transpiration pool and accumulates in the leaves part of the plants. Consequently, excess chloride might cause problems such as necrosis (dead tissue) in plants, which is often accompanied by early leaf drop or defoliation (Horst, 2013). The Total Dissolved Solids (TDS) is the sum of all cations and anions present in the water, related to the amount of dissolved salts in the water. TDS concentrations in the studied samples varies with mean values from $417.00-1378.0 \mathrm{mg} / \mathrm{l}$. Higher salinity results in water results in higher electrical conductivity values (Table 5). The high or very high measure of TDS in groundwater develops soil salinity and also affects the physical properties and fertility of soil (Daliakopoulos et al., 2016). Only sample 4 is suitable for all crops (Table 7). Sample 3 had the highest mean value $(1378.0 \mathrm{mg} / \mathrm{l})$, in conformity with the salinity quality index expressed in percent $(1.08 \%)$, which has shown a relatively high value (Table 5). Samples 1, 2,3 , and 5 are unfit for irrigation agriculture except for tolerant crops. As the salt level increases, the plant must expend more energy to take in nutrients dissolved in the water from fertilizer and the soil. Some plants 
are very sensitive to salinity, while others can tolerate a wide range (Table 7). All the analytical parameters used in assessing Drinking and Irrigation Groundwater Quality in the study site reflect inconsistency among

Table 7 Suitability of water for irrigation based on Total Dissolved Salts (Ayers and Westcot, 1985)

\begin{tabular}{|c|c|c|c|}
\hline TDS (mg/l) & & Number of samples & Quality remark \\
\hline $0-300$ & Suitable for all crops & 4 & Very Low \\
\hline $301-600$ & Suitable for all except extremely Sensitive crops & 1 & Low \\
\hline $601-1000$ & $\begin{array}{l}\text { Suitable for moderately tolerant crops and for moderately sensitive crops } \\
\text { if special precautions are taken }\end{array}$ & 2,5 & Medium \\
\hline $1001-1500$ & Suitable for moderately tolerant and highly tolerant crop & 3 & High \\
\hline$>1500$ & $\begin{array}{l}\text { Suitable only for highly tolerant crops and then only with special } \\
\text { precautions }\end{array}$ & - & Very High \\
\hline
\end{tabular}

Conclusions: This study concludes that high electrical conductivity, total dissolved salts, total hardness, ammonia, phosphate, and microorganisms present are major quality hitches in the examined groundwater, signifying that groundwater around Bundung in the Gambia is not fit for consumption and irrigating all crops. It is important, therefore, to further assess the overall hydrogeology of the study area to determine the exact sources of the contaminations that will help in formulating policies and guidelines for proper use and management.

\section{REFERENCES}

Aghazadeh, N; Mogaddam, AA (2010). Assessment of groundwater quality and its suitability for drinking and agricultural uses in the Oshnavieh area, Northwest of Iran. Journal of Environmental protection, 1(01), 30.

Ayers, RS; Westcot, DW (1985). Water quality for agriculture (Vol. 29). Rome: Food and Agriculture Organization of the United Nations.

Bauder, TA; Waskom, RM; Sutherland, PL; Davis, JG; Follett, RH; Soltanpour, PN (2011). Irrigation water quality criteria. Service in action; no. 0.506.

Boisson, S; Engels, D; Gordon, BA; Medlicott, KO; Neira, MP; Montresor, A; Velleman, Y (2016). Water, sanitation and hygiene for accelerating and sustaining progress on neglected tropical diseases: a new Global Strategy 2015-20. International health, 8(suppl_1), i19-i21.

Camara, AS (2012). National data collection report: The Gambia. UNEP-WCMC technical report.

Chaudhary, V; Satheeshkumar, S (2018). Assessment of groundwater quality for drinking and irrigation purposes in arid areas of Rajasthan, India. Applied Water Science, 8(8), 218.
Connor, R. (2015). The United Nations world water development report 2015: water for a sustainable world (Vol. 1). UNESCO publishing.

CSAO-CILSS, (2008). Food Security Profile The Gambia, GRET; IRAM and ICI, EU p25

Daliakopoulos, IN; Tsanis, IK; Koutroulis, A; Kourgialas, NN; Varouchakis, AE; Karatzas, GP; Ritsema, CJ (2016). The threat of soil salinity: A European scale review. Science of the Total Environment, 573, 727-739.

Dochartaigh, O., Brighid, E. (2019). User Guide: Africa groundwater atlas country hydrogeology maps, version 1.0.

Edition, F (2011). Guidelines for drinking-water quality. WHO chronicle, 38(4), 104-8.

Eskicioglu, C; Galvagno, G; Cimon, C (2018). Approaches and processes for ammonia removal from side-streams of municipal effluent treatment plants. Bioresource technology, 268, 797-810.

Fatajo, FS (2010). National issues report on key sector of agriculture (adaptation) in The Gambia. Banjul: UNDP.

Ford, D; Williams, PD (2013). Karst hydrogeology and geomorphology. John Wiley \& Sons.

Frenken, K (2005). Irrigation in Africa in figures: AQUASTAT Survey, 2005 (Vol. 29). Food \& Agriculture Org..

Gerten, D; Hoff, H; Rockström, J; Jägermeyr, J; Kummu, M; Pastor, AV (2013). Towards a revised planetary boundary for consumptive freshwater use: role of environmental flow requirements. Current Opinion in Environmental Sustainability, 5(6), 551-558.

Gray, N (2017). Water technology. CRC Press. 
Hayzoun, H; Garnier, C; Durrieu, G; Lenoble, V; Bancon-Montigny, C; Ouammou, A; Mounier, S (2014). Impact of rapid urbanisation and industrialisation on river sediment metal contamination. Environmental monitoring and assessment, 186(5), 2851-2865.

Horst, RK (2013). Westcott's plant disease handbook (No. 632/H819). New Yark: Springer.

Lawson, S; Jaworski, A (2007). Shopping and chatting: Reports of tourist-host interaction in the Gambia.

Li, P; Wu, J; Qian, H (2013). Assessment of groundwater quality for irrigation purposes and identification of hydrogeochemical evolution mechanisms in Pengyang County, China. Environmental earth sciences, 69(7), 2211-2225.

Momeni, M; Gharedaghi, Z; Amin, MM; Poursafa, P; Mansourian, M (2014). Does water hardness have preventive effect on cardiovascular disease? International journal of preventive medicine, 5(2), 159.

Murtadha, S; Yussof, I; Fauzi, R; Ramli, I (2017). Analysis of groundwater quality for irrigation purposes in shallow aquifers: A case study from West Aceh, Indonesia. Singapore Journal of Tropical Geography, 38(2), 185-200.

Murtaza, G (2011). Optimization of nitrogen useefficiency in rice-wheat cropping system on tile drained salt-affected soils with different textures. First Annual Technical Progress Report for Higher Education Commission (HEC) funded project (July 2010 to June 2013). Inst. Soil Environ. Sci., Univ. Agric., Faisalabad, Pakistan.

Ogunfowokan, AO; Obisanya, JF; Ogunkoya, OO (2013). Salinity and sodium hazards of three streams of different agricultural land use systems in Ile-Ife, Nigeria. Applied Water Science, 3(1), 19-28.

Palamuleni, L; Akoth, M (2015). Physico-chemical and microbial analysis of selected borehole water in Mahikeng, South Africa. International journal of environmental research and public health, 12(8), 8619-8630.

Pandey, PK; Kass, PH; Soupir, ML; Biswas, S; Singh, VP (2014). Contamination of water resources by pathogenic bacteria. Amb Express, 4(1), 51.
Prasanth, SS; Magesh, NS; Jitheshlal, KV; Chandrasekar, N; Gangadhar, K (2012). Evaluation of groundwater quality and its suitability for drinking and agricultural use in the coastal stretch of Alappuzha District, Kerala, India. Applied Water Science, 2(3), 165-175.

Ramachandran, M; Sabarathinam, C; Ulaganthan, K; Paluchamy, A; Sivaji, M; Hameed, S (2012). Mapping of fluoride ions in groundwater of Dindigul district, Tamilnadu, India - using GIS technique. Arabian Journal of Geosciences, 5(3), 433-439.

Rasool, S; Hameed, A; Azooz, MM; Siddiqi, TO; Ahmad, P (2013). Salt stress: causes, types and responses of plants. In Ecophysiology and responses of plants under salt stress (pp. 1-24). Springer, New York, NY.

Rice, EW; Baird, RB; Eaton, AD; Clesceri, LS (2012). APHA (American Public Health Association): Standard method for the examination of water and wastewater. Washington DC (US): AWWA (American Water Works Association) and WEF (Water Environment Federation).

Rout, C; Sharma, A (2011). Assessment of drinking water quality: A case study of Ambala cantonment area, Haryana, India. International journal of environmental sciences, 2(2), 933-945.

Schlüter, T (2008). Geological atlas of Africa. With Notes on.

Seth, ON; Tagbor, TA; Bernard, O (2014). Assessment of chemical quality of groundwater over some rock types in Ashanti region, Ghana. Am. J. Sci. Ind. Res, 5, 1-6.

Sudhakar, A; Narsimha, A (2013). Suitability and assessment of groundwater for irrigation purpose: A case study of Kushaiguda area, Ranga Reddy district, Andhra Pradesh, India. Adv Appl Sci Res, 4(6), 75-81.

World Health Organization (2016). World health statistics 2016: monitoring health for the SDGs sustainable development goals. World Health Organization. 